\title{
Duterte's Pivot to China, and Prospects for Settling the South China Sea Disputes
}

\section{Bruno Hendler*}

\begin{abstract}
This article proposes a theoretical framework for understanding Filipino president Rodrigo Duterte's celebrated 'pivot to China.' It begins by discussing the model of asymmetric relations as a suitable framework for understanding relations between highly unequal states, and the concept of dual structural asymmetry as a means of theorising the triangular relations among the Philippines, the USA and China since the end of the Cold War. Next, it presents various economic and political indicators of the shift in Filipino foreign policy under Duterte. It goes on to propose a theoretical model for identifying the linkages between elements of political economy and international security from the perspective of Brantly Womack's theory of asymmetry. Lastly, it presents three scenarios for resolving the territorial dispute in the South China Sea (SCS) between the Philippines and China: two with maximum gains for one country only, and a third with an acceptable result for both countries as a product of mutual concessions.
\end{abstract}

Keywords: Theory of Asymmetry; double structural asymmetry; South China Sea Disputes; Filipino Foreign Policy; Filipino-Sino relations.

\section{Introduction}

This article proposes a scenario for resolving the current diplomatic deadlock between China and the Philippines, based on the theory of asymmetry (Womack 2006). The central hypothesis is that, despite the great disparities between these two countries, negotiations could lead to mutual concessions, defining a middle ground that would serve the interests of both parties. To this end, the article examines the model of asymmetric relations (MAR), the triangular relations among the Philippines, the USA and China, and Duterte's celebrated 'pivot to China' - put differently, his government's foreign policy turn away from the USA towards China.

Three key questions are addressed. The first is: What theoretical framework can be used to understand the roots of Duterte's pivot to China? This is done in the first two sections,

\footnotetext{
* Federal University of Rio de Janeiro (UFRJ), Rio de Janeiro-RJ, Brazil; bruno_hendler@hotmail.com. ORCID iD 0000-0003-0896-611X.
} 
which discuss (i) the model of asymmetric relations as a suitable framework for analysing relations between states with highly unequal resources and capabilities; and (ii) the concept of dual structural asymmetry (Chiang 2017) as means of explaining the triangular relations between the Philippines, the USA and China following the end of the Cold War. Although focused on state behaviour, the analysis goes beyond a neorealist great powers perspective to present margins of action for smaller states that are enmeshed in asymmetric relations.

The second question is: Which indicators are most useful for outlining the pivot to China and its consequences? This is addressed in the third section, which presents economic (trade, foreign direct investment and financial aid) and political (bilateral agreements, joint military exercises and strategic cooperation) data to demonstrate the shift in Filipino foreign policy under Duterte's presidency. Going back to the early 2000s, the theory of double structural asymmetry is used to outline and examine the Filipino equi-balancing policy between China and the USA.

The third question is: What theoretical implications can we extract from this case? To this end, the fourth section proposes a theoretical model for identifying the linkages between elements of political economy and international security from the perspective of the MAR. Using the territorial disputes in the South China Sea (SCS) between the Philippines and China as a case study, it presents three scenarios, resulting from a game theory analysis of the negotiations: a) the best outcome for China, and the worst outcome for the Philippines; b) the best outcome for the Philippines, and the worst outcome for China; and c) an acceptable outcome for both, resulting from mutual concessions.

\section{The model of asymmetric relations}

The theoretical framework for this article is Brantly Womack's theory of asymmetry. Womack (2006: 34) studies historical relations between China and Vietnam in terms of their 'basic parameters of international insertion,' defined as 'basic realities of a country's situation that help determine how it views relations with other countries.' While the author acknowledges that these parameters can change, they do so very slowly. The asymmetry between a stronger state (A) and a weaker state (b) is a given, derived from the differences between the basic parameters, and involves demography, territory, internal political structures, social cohesion, access to resources, and so on. Because these parameters are mainly stable, Womack argues that Vietnam will probably remain in the (b) position, and China in the $(\mathrm{A})$ position.

The model of asymmetric relations rests on some basic premises. First, an asymmetrical relationship does not necessarily mean that (A) exerts absolute control over (b): on the contrary, this only occurs when the stronger side is unable to totally subdue or defeat the weaker one. In the face of a stalemate, or when annexation is impossible, both are pushed into a 'normal', negotiated, relationship of asymmetry.

Second, most asymmetric relations display a pattern of stability, and open conflict is the exception. Thus, the object of study in the theory of asymmetry is the handling of asymmetric bilateral relations, and how these can bring costs or benefits to both sides. 
Third, an asymmetric relation is made up of two distinct sub-relations: (A) $=>$ (b) and (b) => (A) (Womack 2004: 78), defined by different degrees of vulnerability. Since the basic parameters are different, the agents' mutual goals and expectations can converge, even in a situation of asymmetry. Still, the general rule is that (b) tends to be more sensitive and vulnerable to (A) than vice versa. For this assumption, Womack borrows the concept of vulnerability as the ability of a state to respond to external stimuli, whether as threats or opportunities, from Robert Keohane and Joseph Nye (2011).

Proceeding from these premises, we can now summarise the key points of the theory of asymmetry.

Differences in expectations. (A) expects deference and submission from (b) - that is, (A) expects that the asymmetric relationship will not be threatened by political-military actions, or by economic competition in strategic sectors. On the other hand, (b) expects that its autonomy, interests and expectations should be recognised and respected, both in terms of security and economic development. It is precisely the field of dispute between deference to (A) and the autonomy of (b), expressed in material and symbolic actions, that can lead to a stable asymmetry or to conflict, which brings us to the next point.

Differences in mutual attention: Given the asymmetry between their basic parameters, (A) devotes less attention to (b) than vice versa, and its foreign policy tends to be more responsive to and less coordinated with (b) because it has more extensive external concerns (Womack 2006: 81). On the other hand, (b) has a more proactive and coordinated foreign policy towards (A) because it is more sensitive and vulnerable to its actions. Therefore, both threats and benefits tend to be more relevant to (b) than to (A).

Figure 1: The politics of asymmetry and asymmetric attention

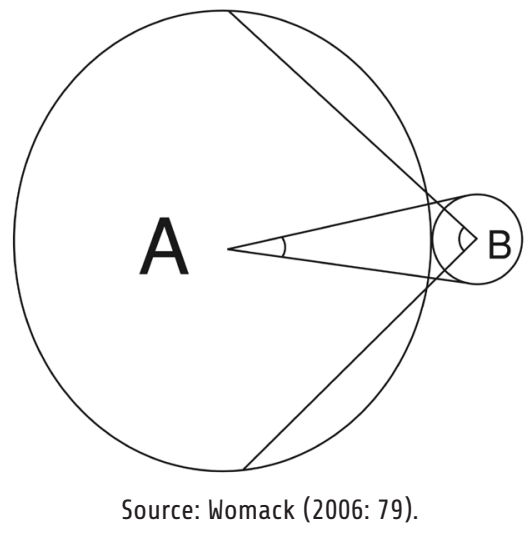

Mutual misperceptions: The difference in mutual attention leads to two ideal types of vicious cycles: bullying and paranoia. The stronger side becomes a bully, using its power and wealth to maintain its dominance over the weaker side and to continue exacting its deference. The weaker side adopts a posture of paranoia, feeling surrounded by the actions of the stronger, and seeing its autonomy threatened (Womack 2006: 85).

Conflict, stalemate and normalisation: Bearing in mind their historical relationship, Womack suggests that conflicts between China and Vietnam derive from a vicious cycle 
of bullying and paranoia, acquiring the characteristics of 'heroic resistance' on the one hand, and 'punitive missions' on the other. Examples such as China's invasion of Vietnam during the Yuan and Ming dynasties in the $14^{\text {th }}$ and $15^{\text {th }}$ centuries, and the clashes between the People's Republic of China and the Socialist Republic of Vietnam in 1979, reinforce this thesis.

Stalemate is reached when both sides realise that they cannot achieve victory in the short term (in other words, resolve the conflict via unilateral action). The frustration resulting from this dead end pushes both countries towards a negotiated, albeit asymmetric, resolution. (A) is frustrated by not being able to impose its will, despite its strength, and the fact that its reputation, self-image and credibility has been tainted. And (b), which suffers more from the material costs of the conflict (at least in relative terms), tends to promptly enter negotiations, and make more concessions.

Peace agreements tend to re-establish the basis of the deference-autonomy dichotomy through a normalisation process (Womack 2006: 88). The post-conflict window of negotiations can be analysed in terms of Robert Putnam's two-level game theory (1988), which provides a tool for examining the adjustment between domestic interests and interstate negotiations. In sum, the author suggests that both states must make concessions that are acceptable to their internal publics - or, put more technically, correspond to possible 'wins' in domestic 'win-sets' of interests. Agreements are reached when the 'win-sets' of the two states overlap to some degree. Naturally, bargaining power will vary according to the end-of-conflict conjuncture, but the basic asymmetry between (A) and (b) will remain a key factor.

Once the conflict is over, relations tend to move from normalisation to normality, which means the gradual construction of channels of contact such as inclusive rhetoric, the routinisation of processes, the establishment of joint technical commissions, diplomatic rituals, and dialogue in multilateral forums (Womack 2006). These processes create a neutral zone that reduces mistrust and mutual resentment, rendering the use of force unlikely, and ultimately halting the vicious cycle of bullying-paranoia.

\section{The roots of Filipino triangular diplomacy}

Jeremy Chiang (2017) uses Womack's theoretical model to interpret Filipino relations with two stronger states, namely the USA and China. For Chiang (2017: 6), South East Asian countries have fallen into a dual structural asymmetry in an 'external environment not pressured by one bilateral relationship, but two equally important asymmetries with China and the USA, which intertwine with China's and the USA's regional geopolitical competition.' In this triangular dynamic, he argues, Sino-American relations present intrinsic challenges to smaller states, which need to balance relations of autonomy and deference with the dominant country while avoiding being caught a vicious cycle of bullyingparanoia.

Since gaining its independence in 1946, the Philippines has maintained a special relationship with its former colonial power, the USA. The Military Bases Agreement (1947) and the Mutual Defense Treaty (1951), signed in the heat of the Cold War, turned the 
Philippines into an important American ally for the containment of communism in Asia, in a tactic of bilateral alliances known as hub-and-spoke (Albert 2016). The Military Bases Agreement remained in force until 1992 when the Filipino government, inspired by other US allies as well as a growing nationalism, saw no reason to maintain a close relationship with its former colonial power, and opted to close US bases. Nevertheless, nearly half a century under the American security umbrella had strengthened ties between the two countries; the Filipino economy remained dependent on the USA, its military forces were structured with US cooperation, and the Filipino immigrant community in the USA grew considerably.

Figure 2: Double asymmetric relations between the Philippines, the USA and China

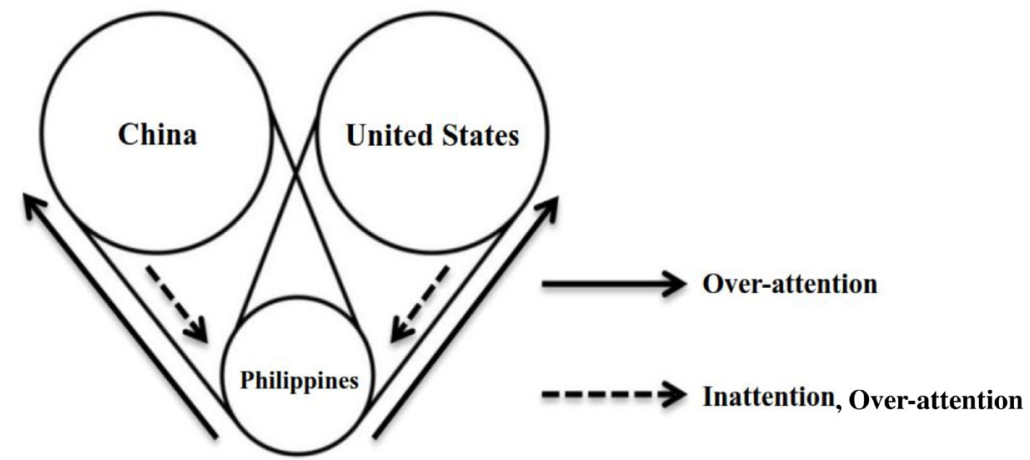

*The dotted line should only denote inattention; however, for reasons of intellectual property, the original legend has been retained.

Source: Chiang (2017: 6).

On the other hand, the Philippines perceived Mainland China as a threat until the normalisation of diplomatic relations in 1975. It feared communist contagion, because of Chinese support for the guerrillas in Mindanao, and the Chinese diaspora in the country was regarded with distrust. Over the following two decades (1975-95), this bilateral relationship became cordial despite low levels of economic interaction (San Pablo-Baviera 2009: 174). Moreover, until the mid-1990s, the asymmetry between China and the Philippines was not as evident as in the following decades, and the special Filipino relationship with the USA ensured some economic support and security in the government's fight against domestic communist forces supported by China.

The dilemmas of asymmetry with the great powers were evident in the 1990s. The Chinese threat of communist diffusion was replaced by a geopolitical threat when the Filipino Navy discovered Chinese naval patrols and constructions in Mischief Reef (the Spratly Islands) in 1995 and 1997 (Goh 2008: 134). As a result, in 1998/9, the Filipino government negotiated the return of US forces under the Visiting Forces Agreement, ending the brief hiatus in their military relationship, while also giving the foreign presence a temporary façade, in order to appease public opinion. Control over (or at least access to) the SCS is important for both China and the Philippines, because both countries face similar challenges in the form of large populations, the over-exploitation of resources, 
environmental crises, and threats of energy shortages (San Pablo-Baviera 2009: 175). But the asymmetry of material capabilities, which were obvious in the 1990s, makes the Philippines far more sensitive and vulnerable to events in the SCS, the more so given its inevitably maritime vocation.

The triangular relationship among the Philippines, the USA and China became even more complex after the Asian financial crisis of 1997. China launched a diplomatic charm offensive: it rescued South East Asian economies with larger financial packages than those of the IMF; incurred high trade deficits with the Global South (including the Philippines) in order to become an alternative pole in the world economy (Medeiros 2008: 256); and joined many organisations and international regimes in order to reduce the distrust of its neighbours. Following 9/11, the USA turned South East Asia into a second major theatre of the 'War on Terror,' and strengthened its alliances with Japan, Australia, Singapore and Indonesia (San Pablo-Baviera 2009: 185). Thereafter, the Sino-American dispute in AsiaPacific, although overshadowed by the conflicts in Iraq and Afghanistan, gained greater relevance, impacting on the foreign policy of the countries in the region.

In this scenario of increasing competition between the great powers, the Filipino president Gloria Macapagal-Arroyo (2001-2010) implemented a policy of equi-balancing (Castro 2016: 139). Arroyo visited the USA in November 2001, received US president George W Bush in 2003, and strengthened security cooperation in the context of the 'War on Terror. US military assistance rose from US\$38m in 2001 to US\$114m in 2003; the country received, along with Thailand, the status of major non-NATO ally, and became a centre of logistics operations for the US military; and its armed forces received training on how to combat the guerrillas in the south of the country (Chiang 2017: 11). However, after the kidnapping of a Filipino worker, Angelo de la Cruz, in Iraq in 2004, Arroyo withdrew Filipino supporting troops from Iraq, and relations with the USA were temporarily disrupted.

Arroyo established closer ties with Hu Jintao's China, with the two parties declaring a 'golden age of partnership.' China also provided the Philippines with military assistance to the value of about US $\$ 1.2 \mathrm{~m}$ (still a lot less than the value of military assistance from the USA), invited it to participate in joint military exercises, and signed a series of memoranda of cooperation in respect of defence and security (San Pablo-Baviera 2009: 175). After the cooling of relations with the USA, the number of agreements with China grew significantly from 25 (in 2001-2004) to 52 (in 2005-2007). Overall, Arroyo concluded 83 agreements with China, in contrast with 15 under her predecessor Joseph Estrada and nine under her successor Benigno Aquino III, including agreements on sensitive issues such as cooperation on the SCS (Clemente 2016: 222).

Arroyo therefore used competition between the great powers to gain benefits from both sides, because it was precisely the Sino-Filipino rapprochement that forced the Americans to move on from the Angelo de la Cruz case, increase financial aid once again, and reach new cooperation agreements in 2006 to deal with insurgency, piracy, natural disasters, diseases, and other unconventional threats (Goh 2008: 138).

Nevertheless, the end of the Arroyo government was marked by allegations of corruption involving Chinese investments, and renewed friction with China. In March 2009, 
Arroyo approved the Philippine Archipelagic Baselines Law, which defines the territorial jurisdiction of the country and includes the Scarborough Reef. In May 2009, China presented the UN with the Nine-Dash Line, defining its territorial demands in the SCS, which overlaps the 200-mile exclusive economic zones (EEZs) of numerous South East Asian countries. As a result, the number of bilateral agreements between the Philippines and China fell abruptly, resulting in bilateral relations cooling down.

The next president, Benigno S Aquino III (2010-16), rose to power on the back of criticism of the rapprochement with China. Despite this, during his first year, he deferred to China by not sending representatives to the 2010 Nobel Prize ceremony which honoured the Chinese dissident Liu Xiabo, and by extraditing Taiwan citizens charged with electronic fraud (Chiang 2017: 16). However, attesting to the workings of structural asymmetry, the stronger side, Beijing, ignored these signs and stepped up its bullying policy in the SCS (Chiang 2017: 13), generating friction between the Filipino and Chinese navies around the oil exploration on the Reed Bank, and harassing Filipino fishermen around the Scarborough Reef.

In 2012, Aquino challenged China's territorial claims in the SCS at the Permanent Court of Arbitration in terms of the UN Convention on the Law of the Sea (UNCLOS), which cooled bilateral relations (Chiang 2017: 16).

In keeping with the swings of the pendulum in triangular diplomacy, Aquino found US support in the form of president Barack Obama's Pivot to Asia policy, which sought to strengthen ties in the region in order to counterbalance China. The parties reached the Framework Agreement on Enhanced Rotational Presence in 2012, and the Enhanced Defense Cooperation Agreement (EDCA) in 2014 (Amador, Merced and Teodoro 2015). These agreements can be seen as updating the Mutual Defence Treaty of 1951, as they grant US forces access to military facilities in the Philippines in return for military modernisation, the transfer and maintenance of equipment to local forces, and providing aid to the Filipino Coast Guard for maritime surveillance (Chiang 2017: 17; Castro 2016: 143). Furthermore, Aquino also strengthened military cooperation with Japan, signing maritime security agreements, and purchasing vessels, naval technology and supplies (Castro 2016: 144).

China may have perceived these moves as a threat, for three reasons: first, because they implied the quasi-permanent return of American forces in the Philippines; second, because they expanded Japan's influence over the Philippines; and finally, because the concept of rotating US forces in the Philippines could serve as an example for other countries that felt threatened by China, such as Vietnam and Malaysia (Castro 2016: 144). In short, after a decade of Arroyo's equi-balancing with a smart move towards China, Aquino moved away from Beijing, and strengthened ties with the USA.

\section{Duterte's pivot to China}

Rodrigo Duterte's rise to power changed the direction of the pendulum once again. He ascended to the presidency in July 2016 following an election campaign in which he de- 
fended the massive use of force against drug users as well as guerrilla groupings in the south of the country. He also promised to move away from the USA, and closer to China. These promises were met in the first year of his administration.

The rupture with the USA began in the first months when Duterte declared that he would terminate joint military exercises with US forces, as well as the US Navy's use of Filipino ports for operations in the SCS (Chiang 2017: 18). What seemed to be the last joint military exercise with the USA took place in 2017. Moreover, Duterte insulted US president Barack Obama during the ASEAN Summit held in Laos in May 2016, and on another occasion, he stated that the Philippines would divorce the USA and form alliances along different ideological lines with China and Russia.

The reasons for Duterte's rupture with the USA are unclear, but one explanation might be his biography. He grew up in a family of politicians on the island of Mindanao, lived with the violence of the guerrilla movements, and witnessed the rough activities of American military forces in the region. He has used his resentment as a political tool, constantly referring to the abuses committed by the USA during the colonial period (1898-1946). Lastly, he might have been offended by Obama's heavy criticism of his 'war on drugs' (The Guardian 2016a), which has claimed the lives of some 3000 people thus far.

However, more impersonal economic and ideological forces - notably those related to the rise of China - have also played an important role. Chiang (2017: 20) argues that Duterte has used national identity to move away from Aquino's 'pivot' to the USA, as territorial disputes with China would surely trigger Filipino nationalism, but an unconditional alignment with the USA would counter the economic opportunities presented by China. Thus Duterte seems to adopt two paths to reduce this dependency on or vulnerability to the Americans: seeking opportunities for economic development from China and enhancing strategic ties with Japan, if not to replace, at least to complement the US role as a big partner in naval security.

The main indicator of economic rapprochement with China is foreign direct investment (FDI) in projects costing more than US\$100m. Table 1 shows that administrations closer to China received more investments. Arroyo's second term, the so-called golden age of partnership, attracted five projects to the value of US\$3.3b. During the Aquino government, investments fell to three projects to the value of US\$1.9b. Finally, after a little more than a year, the Duterte government had already attracted eight projects to the value of US $\$ 4.2 \mathrm{~b}$.

Another characteristic of Chinese FDI in the Philippines is the gradual reduction of investment in the energy sector, coal in particular (Figure 2). This is due to the Chinese government's efforts to encourage renewable energy, as well as the opportunities offered by Duterte's government in areas such as tourism, construction and transport.

Table 1: Chinese FDI in the Philippines under three presidents, 2008-2017 (US\$m)

\begin{tabular}{llll}
\hline Year & Value of projects & \# of projects & President \\
\hline 2008 & $\$ 1.580$ & 1 & \\
2009 & $\$ 690$ & 2 & Arroyo \\
2010 & $\$ 1.060$ & 2 & \\
\hline
\end{tabular}


Table 1: continuation

\begin{tabular}{llll}
\hline Year & Value of projects & \# of projects & President \\
\hline 2011 & $\$ 0$ & 0 & \\
2012 & $\$ 350$ & 1 & \\
2013 & $\$ 600$ & 1 & Aquino III \\
2014 & $\$ 1.000$ & 1 & \\
2015 & $\$ 0$ & 0 & Duterte \\
\hline 2016 & $\$ 3.340$ & 6 & \\
2017 & $\$ 910$ & 2 & \\
\hline Total & $\$ 9.530$ & 16 &
\end{tabular}

Table 2: Chinese FDI in energy versus total FDI, 2005-2017 (US\$m)

\begin{tabular}{llll}
\hline & $\mathbf{2 0 0 5 - 2 0 1 0}$ (Arroyo) & 2011-2015 (Aquino) & 2016-2017 (Duterte) \\
\hline FDI in energy & $\$ 3.220$ & $\$ 1.600$ & $\$ 2.990$ \\
Total FDI & $\$ 3.330$ & $\$ 1.950$ & $\$ 4.250$ \\
Energy/total FDI & $96 \%$ & $82 \%$ & $70 \%$ \\
\hline
\end{tabular}

Source: China Global Investment Tracker (2018).

Trade balance data displays a different dynamic. Figure 3 shows the balance of Filipino trade with the USA and China from 2001 to 2016. Until 2004, the balance of trade with China was close to zero, but from 2005 to 2010 it showed a surplus (except in 2009). In this period, China's demand for primary products grew rapidly, enhancing Filipino exports of nickel, copper, oil and coal, but electronic products such as optical readers and conductors also comprised an important part of the export agenda. In 2005, the Philippines also joined China's Early Harvest programme, which led to modest increases in the exports of tropical fruits like bananas, mangoes and papayas, as well as vegetable oil.

While Filipino trade with the USA was in deficit from 2002 to 2005, it was in surplus from then until 2016 (except in 2012). Major exports were electronic products such as cables, conductors and transformers, and primary products such as tropical fruits and tropical fruit oil. The surplus was partly due to the participation of the Philippines in the US General System of Preferences.

However, the trade balance with China declined sharply after the China-ASEAN Free Trade Agreement (CAFTA) came into force in 2010, largely due to the influx of Chinese products like electronics, toys, textiles, footwear and diesel fuel. Moreover, growing geopolitical tensions led to China raising non-tariff barriers to the import of tropical products from the Philippines (Clemente 2016: 217). Therefore, while the Arroyo government enjoyed a trade surplus in respect of China, Aquino had to deal with a flood of Chinese products as well as non-tariff barriers against Filipino products. Although it is too early to evaluate Duterte's trade policies, this will be an inevitable challenge in the coming years. 
Consequently, China surpassed the USA and Japan as the main exporter to the Philippines (Figure 4).

Figure 3: Balance of Filipino trade with the USA and China, 2001-2016

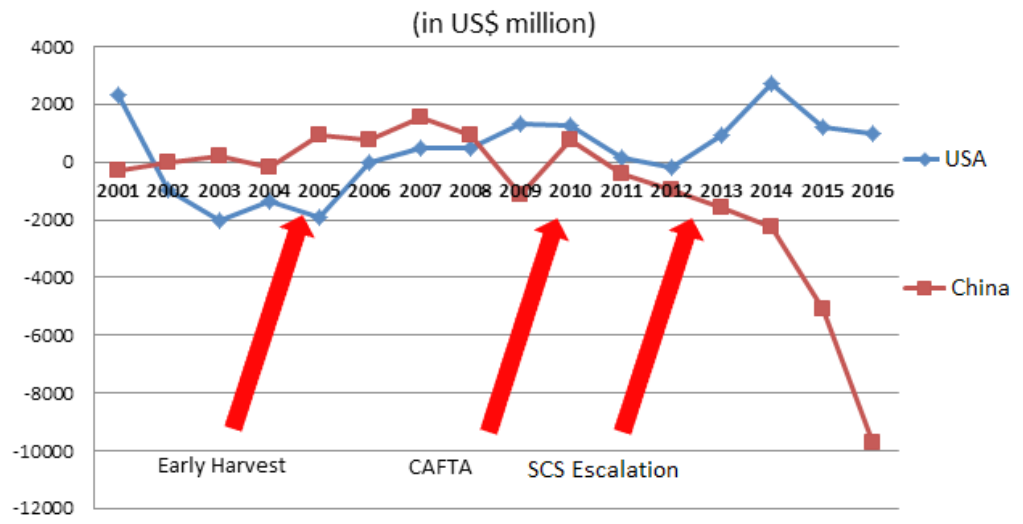

Source: Compiled by the author based on data from International Trade Centre (2018).

Figure 4: Relative participation of main exporters to the Philippines, 2001-2016

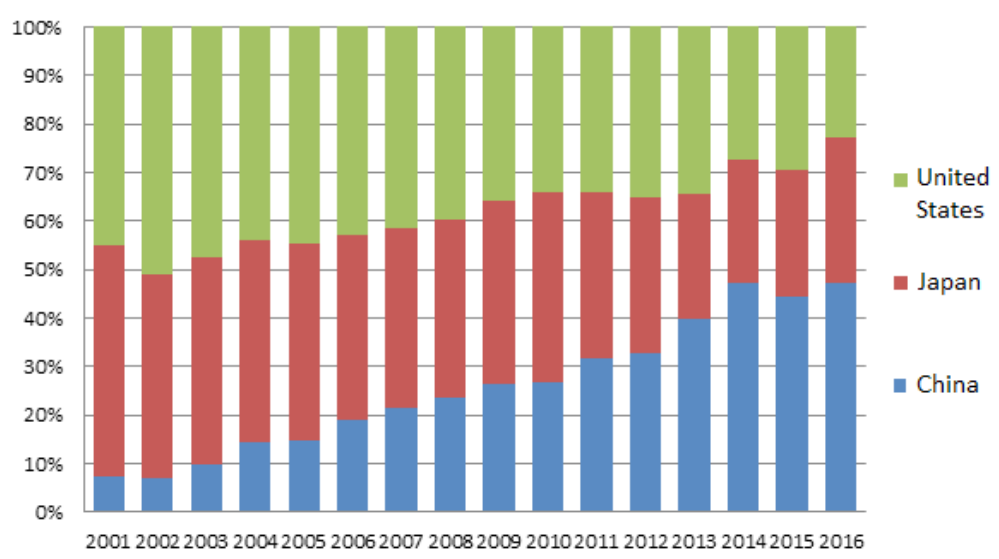

Source: Compiled by the author based on data from International Trade Centre (2018).

US financial aid to the Philippines is another interesting indicator of triangular diplomacy (Figure 5). During the two Arroyo terms of office, economic and military aid amounted to about US\$160m a year. In the first year of the Aquino government, this leapt to US\$600m, and in the following years remained steady at about US\$336m. Military aid increased from US\$38m in 2011 to US\$100m in 2015. Curiously, in 2016, economic aid fell from US\$153m to US\$123m, the lowest value since 2009, but military aid rose from US\$100m to US\$152m.

In the security sector, there were two processes that indicated Duterte's turn towards a less hostile stance towards China. The first was the timid reception of the favourable decision by the Permanent Court of Arbitration (PCA) about the SCS (The Guardian 2016b). 
The decision was announced in July 2016, two months after Duterte's election, and he adopted a much more moderate stance than his predecessor, defending a negotiated resolution with China and a possible agreement over the joint exploration of resources in the SCS. At the ASEAN Summit in Laos in September 2016, Duterte confirmed his moderate position by stating that the opinion of the PCA was a purely bilateral issue, and endorsing the veto of Cambodia and Laos to a Joint Declaration under the veiled influence of China (Mogato et al 2016). This declaration contained references to legal and diplomatic procedures for resolving the SCS imbroglio, and criticized China's aggressive stance, but due to the vetoes it was not ratified by consensus in the bloc (Castro 2016: 147).

Figure 5: US financial aid to the Philippines, 2001-2016 (US\$m)

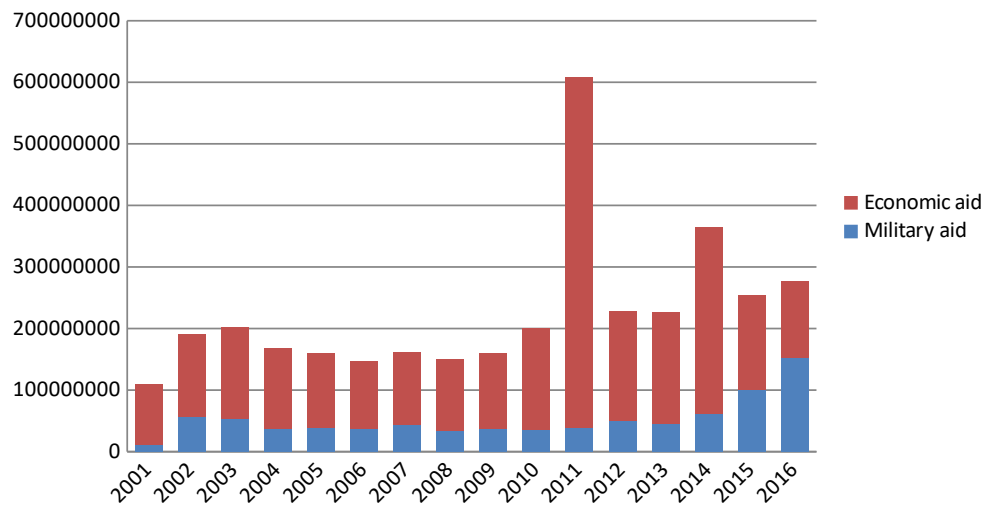

Source: Compiled by the author based on data from USAID (2018).

The second process was the rapprochement with Japan over security cooperation, which reflected the strong economic interdependence between the two countries. Japan is one of the main investors in the Philippines, and the country's main trading partner. In an official visit to Tokyo in October 2016, Duterte sought not only to attract investment in transport infrastructure, but also agreements in the military sphere, emphasising technology and supplies. Agreements were signed for the transfer of vessels and equipment to the Philippine Naval Guard, and for the provision of military training. Finally, in a joint statement, Duterte and his Japanese counterpart emphasised freedom of navigation and flight over the SCS (Castro 2016: 153-154).

Therefore, in the economic sphere. we have some indicators of Duterte's diplomatic turn. Regarding China, the most relevant variable is the attraction of FDI, which rose in absolute value, the number of projects, and the number of sectors. The detachment from the USA was also clear during the last year of Obama's administration. However, since Trump's ascent to power, Duterte seems to have adopted a more moderate approach to the USA, due to its assistance in the struggle against Abu-Sayyaf, and Trump's turning a blind eye to alleged human rights violations in the course of Duterte's War on Drugs (Kurlantzick 2017). It is no coincidence that US military aid to Manila kept growing in 2016, despite a decline in economic aid (Figure 1). 
In the commercial sphere, the trade deficit with China is likely to continue due to the asymmetry in absolute terms, and the gap in economic sophistication in relative terms. On the other hand, the trade surplus with the USA tends to continue mainly because of privileged access to the American market (thanks to the GSP), but also because of the Trump's administration withdrawal from the Transpacific Partnership, which could have triggered the same kind of reversal as CAFTA caused with China. And in security issues, we see a slight reduction in cooperation with the USA, but also a continuity with the Aquino government, namely the strengthening of ties with Japan in order to minimise its reliance on the USA.

\section{Patterns of interaction in asymmetric relations}

We will now propose a model for depicting the interaction between political economy and security in a set of asymmetric relations. It is purely conceptual, and does not use quantitative indicators to calculate the position of the actors. Moreover, while we have discussed the double structural asymmetry of the Philippines with the USA and China, this model only depicts asymmetric relations between two states and not three.

The model takes the form of a matrix with four quadrants, arranged around a vertical and a horizontal axis. The vertical axis represents gains or losses in the field of 'hard politics' - i.e., the dynamics of political and military power. The horizontal axis represents gains or losses in the field of political economy - i.e., the dynamics of wealth creation and insertion into global value chains.

Figure 6 utilises this matrix to depict the basic asymmetric relations between the Philippines and China in respect of territorial disputes. It reflects processes that are still relevant in 2017-2018, but also takes into account the historical dynamics discussed in the previous sections.

With regard to the economic axis, the Philippines is further to the right because of its economic activities in the SCS, especially fishing, but also because its exploitation of energy resources constitute (or may constitute in the future, in the case of energy) a greater proportion of its GDP than China's. Thus the distance between the Philippines and China on the horizontal axis results from their major economic asymmetry, and the relative importance of fishing and the exploitation of energy resources for the Philippines. This means that, while these activities may have positive impacts on southern Chinese provinces, the Filipino economy may benefit far more in relative terms from economic access to the SCS than China's.

For China, the economic relevance of the SCS is mixed with the logic of security: the SCS region is more important to China because of trade routes than because of its natural resources. China is in the middle of the vertical (political) axis, for several reasons. On the one hand, its control over the SCS represents strategic gains due to access for its bluewater navy, the protection of maritime routes, and military outreach. On the other hand, the construction of artificial islands and the non-observance of both the PCA's decision and the principle of free navigation of the seas would jeopardise China's soft power effort 
to join regional security institutions, and strengthen bilateral diplomatic ties. Therefore, China's initial position on the political axis is centred, as its gains and losses, or costs and benefits, tend to balance out.

Figure 6: Gains and losses in territorial disputes between China and the Philippines

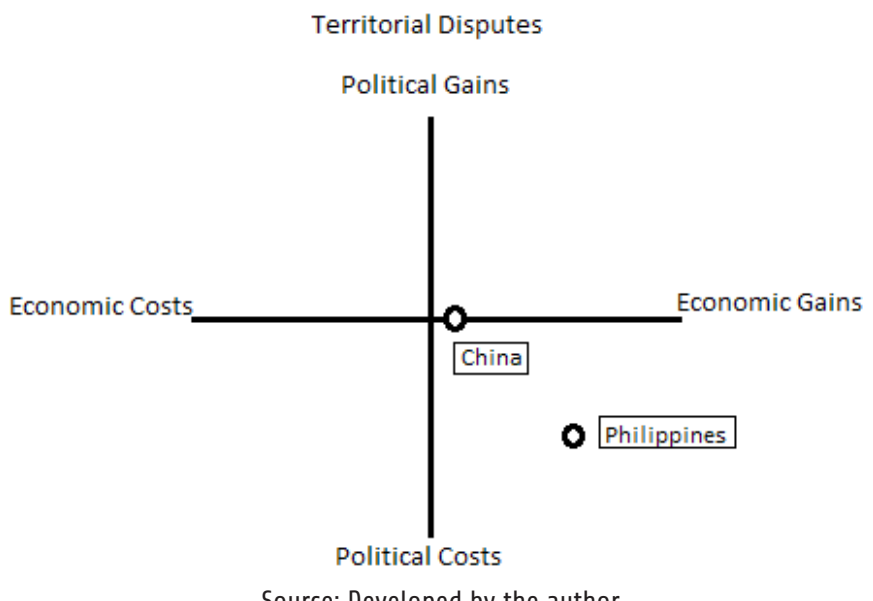

Source: Developed by the author.

By contrast, the Philippines has more to lose than to gain in the politico-military arena. Its strategic options are constrained by internal threats (guerrillas and drug trafficking), external threats (such as China's maritime bullying), and the historical reliance on US cooperation/protection, resulting in a defensive strategic mindset. Thus, conditions such as its low-middle-income country status, the lack of efficiency in resolving internal threats, the reliance on sea lanes, and the simple asymmetry of military force vis-à-vis China make the Philippines an actor with much more to lose strategically in the SCS, no matter how many international tribunals vote in its favour.

\section{Options for settling the litigation in the South China Seas}

These conditions and possibilities make up a two-level game (Putnam 1988). In economic terms, the maximum gain for both sides would be a monopoly over the exploitation of resources in the SCS. China would still have an advantage, as natural gas and oil can be extracted by Chinese companies, while the Philippines would need to attract foreign companies, despite the high risk of conflict with China. As regards fishing, both countries are autonomous, but this activity is proportionally more relevant to the Philippine economy. The ideal resolution of the current impasse would be joint exploration by China and the Philippines, a process that started during the Arroyo government in 2004 and also included Vietnam, but was discontinued a few years later due to mutual distrust. Now, under Duterte and $\mathrm{Xi}$, a new perspective on joint fishing activities seems to be developing.

In strategic terms, the basic asymmetry between the two countries creates different expectations of a resolution. China's basic parameters involve a historical narrative of the 
centrality of its tribute system in South East Asia; a conception of the southern borders (on land and sea) as expansive and mobile (unlike the rather defensive and static borders in the north and west); the notion of being under siege by the West, due to the US system of hubs and spokes; and, above all, a material force used by a strong and organised state to project power over a region that does not host any major powers or countries with a nuclear capability.

The Philippines is an archipelago with a long colonial past, marked by social inequality, two major domestic threats (drug trafficking and guerrillas), and armed forces that, despite Duterte's current turn to China, still rely on cooperation with the USA. While this special relationship provides it with a degree of domestic stability and security against internal and external threats, it restricts the country's geopolitical ambitions, and maintains it as one of numerous pawns of American strategy in the Asian geopolitical theatre.

Thus, expectations of negotiation on the geopolitical board between the two countries are distinct. The optimal outcome for China is absolute control over the SCS (according to the Nine Dash Line), and a monopoly over resource exploitation. A possible concession, signalled on some occasions to different litigating countries, is the joint exploitation of resources without giving up de facto political-military control, expressed by the occupation of most of the islands and also by the transformation of islets and sandbars into real islands. In addition, China would have to recognise the de facto possession of some islands, islets and sandbanks by other countries, and give up bullying foreign fishing boats. Finally, the worst scenario for China in dealing with the Philippines is shared political-military control of Scarborough Shoal, in an arrangement in which US and Japanese forces, under international law, would protect and strengthen the safety of Philippine forces.

For the Philippines, the optimum result would be military control over its EEZ of 200 nautical miles, including the reefs and islets of the Spratly Islands and the Scarborough Shoal. Since such absolute control is not feasible, a possible concession is to accept China's de facto jurisdiction over many of these islands in exchange for the joint exploitation of resources and the maintenance of Philippine forces on the few islets under its own control. Joint exploration would consist of: a) giving Philippine fishing boats access to the entire region; and b) shared royalties from the exploitation of oil and natural gas reserves although this may be resisted in the Philippine Congress and in the military. Finally, the worst scenario for the Philippines would be a lack or loss of political-military control of its EEZ, a Chinese veto over fishing activities, and exclusion from the exploitation of energy resources.

Figure 4 depicts the movements China and the Philippines would need to make to resolve their dispute. It reflects 'acceptable' results for both sides, in which their win-sets would overlap. For China, this would mean smaller economic gains, but significantly greater political gains. For the Philippines, it would mean greater economic gains, but also greater political costs.

By making concessions such as allowing the Philippines to practise fishing and permitting a de facto possession of small portions of the Spratlys, such as the Kalayaan Islands, China would make far greater political gains. First, as the stronger state (A), this would 
signal a degree of respect for the autonomy of the weaker state (b), and avoid signs of bullying, interpreted as aggression by the weaker side. Second, it would reduce the sense of threat held by other litigating countries, which would tend to follow the behaviour of the Philippines and tacitly accept a Chinese preponderance. And third, it would deflate the justification for the US presence in the region, namely to guarantee its stability. On the other hand, its economic gains would be low, at least in the short term, because fishing is less important to the Chinese economy, and oil and gas exploitation would demand large initial investments and the sharing of royalties with the Philippines.

Figure 7: Scenario for resolving the SCS dispute between China and the Philippines Territorial Disputes

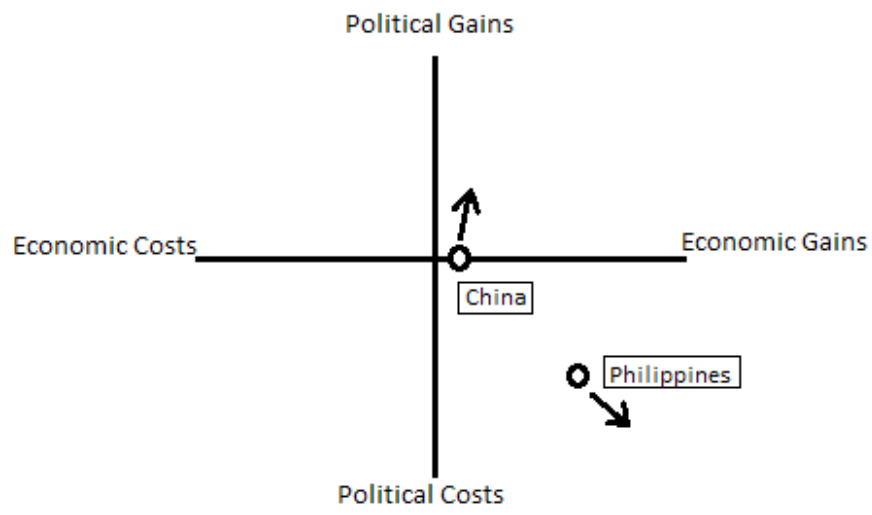

Source: Developed by the author.

Conversely, for the Philippines, the 'acceptable' result would mean economic gains and political setbacks. The economic gains would result from fishing, and a share in oil and gas royalties. The political costs would be the loss of control over its 200-mile EEZ, despite the possession of a few islands, and also the tacit, almost inevitable, recognition of Chinese supremacy in the region, which would force it to gradually limit cooperation and military exercises with the Americans and the Japanese for fear of losing its economic gains.

There are some obstacles or challenges to reaching a middle ground and avoiding the misperceptions that lead to conflict. On the Chinese side, they are: a) that Chinese companies need to accept the payment of royalties for oil and natural gas to the Philippines, even if the initial investments are made only by the Chinese; b) that the Chinese navy needs to grant autonomy to the Philippines at least in respect of fishing activities, avoiding typical bullying attitudes of (A) over (b), and accepting that Philippine fishermen pose no threat to its de facto sovereignty in Scarborough and parts of the Spratlys; and c) that the Philippine possession of islands such as Kalayaan is informally recognised.

On the Philippine side, the challenges are: a) to pay typical deference from (b) to (A) to China, and recognise its de facto sovereignty by scaling down military cooperation with the Americans and the Japanese; b) to accept that the exploitation of energy resources by 
Chinese companies would also include some Philippine interests; and c) to convince its domestic audience (politicians, the military, and ordinary voters) that a deal with China over energy exploration would be an opportunity instead of a threat.

\section{Final considerations}

The dual structural asymmetry of Filipino relations with the USA and China has moved along several points on this matrix in the past two decades. Arroyo's first term was marked by equi-balancing between the two powers. The return of US influence after the hiatus in the 1990s became clear with the leap in financial aid (both civil and military), diplomatic and presidential visits, and the inclusion of the Philippines in the category of major non-NATO ally in 2003. The number of Filipino bilateral agreements with China also grew, including cooperation initiatives in respect of the SCS. The 2003-4 window may have come the closest to reaching a lasting agreement of mutual gains with small concessions between Manila and Beijing. This is because China had not yet occupied most of the Spratlys, nor tabled its Nine-Dash Line, and the Americans were too busy in Iraq and Afghanistan to exert pressure on the Philippines.

During her second term, Arroyo maintained the equi-balance up to a point, but leaned towards China, because of economic considerations, and because relations with the USA had cooled after the withdrawal of the Philippines from Iraq. Closer relations with China offered great economic opportunities: the Early Harvest programme encouraged exports, large direct investments began to arrive in the energy sector, and bilateral agreements reached a record number of 52 between 2005 and 2007. However, economic convergence was affected by allegations of corruption around Chinese investments, and by the territorial dispute that had entered a new chapter with the Filipino Baselines Law and the Chinese Nine-Dash Line. The golden age of partnership ended, and the win-sets of the two countries drifted apart.

The Aquino administration reached a point where a negotiated settlement with China was most unlikely. The pattern of bullying-paranoia intensified due to friction between coastguards and fishing fleets, with a clear imbalance in favour of China. Tensions increased further due to the legal dispute in the UN Permanent Court of Arbitration and Aquino's strengthening of ties with the USA under Obama, when the double structural asymmetry became prominent once again.

Duterte has pursued another twist in foreign policy. Speeches and 'speech acts' like his presence at the launch of the Belt and Road Initiative in Beijing have set the tone of his ambitions, but his controversial statements make him a somewhat unpredictable player in the international arena. His rapprochement with China will certainly run up against internal limits as the Philippines are essentially a US-friendly society, and many military leaders and politicians are suspicious of China's intentions. Nevertheless, the growth of Chinese FDI can work in Duterte's favour, not only by improving infrastructure, but also by increasing the flow of businessmen, the strengthening of tourism, and investment in renewable energy. 
If Duterte manages to soften his rupture with the USA, especially with a Trump administration which is less concerned with human rights, and combine Japan's military cooperation with traditional American aid rather than swap one for the other, there is a window of possible benefits for the Philippines. It will gain considerable economic benefits from continuing to fish in the SCS, Chinese investment, and possibly receiving a portion of the royalties from the exploitation of energy resources. The cost would be the tacit recognition of China's de facto possession of most of the islands, with Japanese and American support helping to keep the remaining few islands under Philippine control.

\section{References}

Albert, E. 2016. 'The US-Philippines Defense Alliance.' Council on Foreign Relations [online]. At https://www.cfr.org/backgrounder/us-philippines-defense-alliance [Accessed on 10 December 2017].

Amador III, J, L D Merced and J Teodoro. 2015. The Philippines' foreign policy and relations towards major powers. At http://www.centreasia.eu/sites/default/files/publications_pdf/etude_philippines_2015_dgris.pdf [Accessed on 10 December 2017].

Chiang, J. 2017. 'Philippine foreign policy in the 21st century: the influence of double-asymmetric structure.' At http://web.isanet.org/Web/Conferences/HKU2017-s/Archive/e35950e1-db894726-b72e-671a86b59ca3.pdf [Accessed on 10 December 2017].

China Global Investment Tracker (2018). Chinese investment dataset. At http://www.aei.org/chinaglobal-investment-tracker/ [Accessed on 8 December 2017].

Clemente, T S. 2016. 'Understanding the economic diplomacy between the Philippines and China.' International Journal of China Studies 7 (2): 215-233.

Castro, R C. 2016. 'The Duterte administration's foreign policy: unravelling the Aquino administration's balancing agenda on an emergent China.' Journal of Current Southeast Asian Affairs 35 (3): 139-159.

Goh, E. 2008. 'Great powers and hierarchical order in Southeast Asia: analyzing regional security strategies.' International Security 32 (3): 113-157.

International Trade Centre. 2018. Trade Map. At https://www.trademap.org/Bilateral_TS.aspx?nvp $\mathrm{m}=1|076||156| \mid$ TOTAL |||2|1|1|1|2|1|1|1| [Accessed on 3 April 2018].

Keohane, R and R Nye. 2011. Power and Interdependence. 4th edition. New York: Longman.

Kurlantzick, J. 2017. "Is Duterte warming to the United States?" Council of Foreign Relations. At https://www.cfr.org/blog/duterte-warming-united-states [Accessed on 4 April 2018].

Medeiros, C. 2008. 'Desenvolvimento econômico e ascensão nacional: rupturas e transições na Rússia e China.' In C Medeiros, J L Fiori and F Serrano, O mito do colapso do poder americano. Rio de Janeiro: Record.

Mogato, M, M Martina and B Blanchard. 2016. 'ASEAN deadlocked on South China Sea, Cambodia blocks statement'. At https://www.reuters.com/article/us-southchinasea-ruling-asean-idUSKCN1050F6 [Accessed on 26 April 2018].

Putnam, R. 1988. 'Diplomacy and domestic politics: the logic of two-level games.' International Organization 42 (3): 427-460. 
San Pablo-Baviera, A. 2009. 'Waltzing with Goliath: Philippines-China engagement in uncharted waters.' In S Tang, M Li and A Amitav (eds), Living with China: Regional States and China through Crises and Turning Points. New York: Palgrave Macmillan, 173-191.

The Guardian [online]. 2016a. 'Rodrigo Duterte says Obama "can go to hell" and considers breaking up with US.' At https://www.theguardian.com/world/2016/oct/04/philippines-rodrigo-dutertetells-obama-go-to-hell [Accessed on 10 December 2017].

[online]. 2016b. "Philippines to "set aside" South China Sea tribunal ruling to avoid imposing on Beijing.' At https://www.theguardian.com/world/2016/dec/17/philippines-to-set-asidesouth-china-sea-tribunal-ruling-to-avoid-imposing-on-beijing [Accessed on 26 April 2018].

USAID. 2018. Foreign Aid Explorer. At https://explorer.usaid.gov/data.html. [Accessed on 4 April 2018].

Womack, B. 2004. 'Asymmetry Theory and China's concept of multipolarity'. Journal of Contemporary China 13 (39): 351-366. 2006. The Politics of Asymmetry. Cambridge: Cambridge University Press.

\title{
Acknowledgments
}

This research has been supported by a CAPES scholarship for PhD Candidates.

\section{About the author}

Bruno Hendler is a PhD Candidate in International Political Economy at the Federal University of Rio de Janeiro, and holds a Masters of International Relations from the University of Brasília. His research is supported by a CAPES PhD scholarship. He has published widely on China's rise in the $21^{\text {st }}$ century; China's pre-modern tributary system; China-South East Asia relations; China-US relations; World System Analysis; International Political Economy; and International Security Studies. He is currently developing analyses of China's economic statecraft in the Global South, with a focus on South East Asian countries, such as the Philippines, Vietnam, Cambodia and Indonesia.

\section{0 pivô de Duterte para a China e as disputas do Mar do Sul da China}

\begin{abstract}
Resumo: O presente artigo busca desenvolver um arcabouço teórico para entender o célebre "pivô para a China" do presidente filipino Rodrigo Duterte. Inicialmente, discute o modelo de relações assimétricas como um quadro adequado para entender as interações entre Estados altamente desiguais, e o conceito de assimetria estrutural dual como meios de teorizar as relações triangulares entre as Filipinas, os EUA e a China desde o fim da Guerra Fria. Em seguida, apresenta diversos indicadores
\end{abstract}


econômicos e políticos da mudança da política externa filipina sob o governo de Duterte. Propõe, em seguida, um modelo teórico para identificar as ligações entre elementos da economia política e segurança internacional na perspectiva da 'Teoria da Assimetria’ de Brantly Womack. Por fim, apresenta três cenários para resolver a disputa territorial no Mar da China Meridional (SCS) entre as Filipinas e a China: dois com ganhos máximos para apenas um país e um terceiro com um resultado aceitável para ambos os países como produto de concessões mútuas.

Palavras-chave: Teoria da Assimetria; assimetria estrutural dupla; Disputas no Mar do Sul da China; Política Externa das Filipinas; Relações Filipinas-China.

Received on 9 January 2018, and approved for publication on 9 May 2018.

\section{(cc) BY-NC}

https://creativecommons.org/licenses/by-nc/4.0/ 